\title{
Effective Management of Pcos (Polycystic Ovarian Syndrome) through Ayurvedic Panchakarma Therapy Virechan : A Case Study
}

\author{
Wadhwa Ritu. $\mathbf{S}^{1^{*}}$, Ghore Jaya.K ${ }^{2}$ \\ ${ }^{1}$ M.D (Kayachikitsa) Professor Panchakarma, Department Of Panchakarma, D.Y Patil School Of Ayurved \\ Nerul,Navi Mumbai, Maharashtra. India \\ 2.M.D (Kayachikitsa)Associate Professor Panchakarma, Department Of Panchakarma, D.Y Patil School Of \\ Ayurved Nerul,Navi Mumbai, Maharashtra. India
}

*Corresponding Author: Dr. Ritu Wadhwa, M.D (Kayachikitsa) Professor Panchakarma, Department Of Panchakarma, D.Y Patil School Of Ayurved Nerul,Navi Mumbai, Maharashtra. India

\begin{abstract}
A female patient clinically diagnosed with polycystic ovarian syndrome approached in the opd of Dypatil ayurvedic hospital for treatment.patient was planned for virechan karma...Virechan (medical purgation)is one of the main detoxification procedure of ayurvediya panchkarma therapy followed by sansarjana krama. Chikitsa sidhant aims Agnideepan, \& Aampachan hence clearing away the srotorodha leads to apan vatanuloman resulting regularization of menstrual cycle,imbalance hormone \& metabolism, Hence PCOS can be managed with sanshodhan chikitsa \& lifestyle modification.Virechan as sanshodhan treatment was found very effective as patient got significant relief in various symptoms .. After Shodhana, there was reduction in the ovarian volume and number of non dominant follicles in USG .TSH and Lipid profile came to normal. Symptomatically also patient had relief in her symptoms along with six $\mathrm{kg}$. wt. reduction.
\end{abstract}

Keywords: virechan, ,pcos , shodhana

\section{INTRODUCTION}

Polycystic ovary syndrome (PCOS) is a common gynaecological disorder of chronically abnormal ovarian function and hyperandrogenism. It affects 5-10\% of women of reproductive age.It is an ovarian cause of secondary amenorrhoea which hampers normal menstrual cycle but also has marked affliction on the fertility of females. PCOS is heterogeneous endocrine disorder leading to several health complications,

1) Ovulatory and menstrual dysfunction

2) Hyperandrogenemia

3) Features of hyperandrogenism - hirsutism, acne and androgenic alopecia

4) Polycystic ovaries

Polycystic ovaries develop when the ovaries are stimulated to produce excessive amounts of androgenic hormones, in particular testosterone, by either one or a combination of the following (almost certainly combined with genetic susceptibility):

a)the release of excessive luteinizing hormone ( $\mathrm{LH})$ by the anterior pituitary glands.

b)through high levels of insulin in the blood (hyperinsulinaemia) in women whose ovaries are sensitive to this stimulus)

Multifactorial causes have been implicated for pcos . keeping in mind the diversity of presentation of the disease multidisciplinary approach is required from various specialities like obstetrics and gynaecology,dermatology ,medicine, nutrition , ayurveda, yoga and to treat the individual as a whole .The primary treatments for PCOS include: lifestyle changes and medications.

According to Ayurveda PCOS can correlate with several conditions described in Ayurvedic literature. i.e. Granthi, Artavkshayam, Nashtartavam Pushpagni,Jataharini, and Raktagulmam, arajaska, 
ksheenartava .In all these conditions kapha and vata are aggravated doshas,Medas ,mansam and rakta are the vitiated dushyas.

Case report - A female patient of age 24 years, already diagnosed with PCOS visited to opd of streerog and prasutitantra department of D.Y. Patil Ayurved hospital Nerul, Navi Mumbai. She had been referred to dept. of Panchkarma for management with suitable shodhan chikitsa .. She was taking irregular Allopathy and Homeopathy treatment for PCOS since 5 years.. She presented with complains of delayed menstrual cycle, constant weight gain mainly central obesity , hair growth on face (Hirsuitism)and associated symptoms acidity, flatulence, disturbed sleep and heaviness in the abdomen.

USG was also suggestive of Polycystic ovarian disease. After complete examination, blood investigations were done, which revealed increased lipid levels.

Observations: Patient is heavy built with $80 \mathrm{kgs}$ weight, more fat around abdomen. Hair was seen on face. Dull and lethargic look.

Prakriti -kapha vata

Bala -Madhyama

Agni -Mandagni

Koshta -krura.

\section{H/O present illness-}

Past medical history -

No history of any previous major illness.

\section{Family history -}

Not contributory

\section{Personal history-.}

\section{Ashtavidha pariksha:}

Pulse $-68 / \mathrm{min} \quad$ Voice- clear

Tongue-niram Urine- regular

Built- medium ,Eyes- prakrut

Stool- regular Touch-manda, ushna over knee jts.

\section{Dashavidha pariksha}

Region-sadharan Appetite- moderate

Strength - low Prakruti-vata-pitta

Disease- severe Digestive power - moderate

Age -24 yrs mental strength- satva-heen

Diet-junk food consumption kala -10 years

\section{General examination}

Pulse -68/min

BP -110/70 mmhg

Wt.80kg

$\mathrm{Ht}-150 \mathrm{~cm}$

$\mathrm{Bmi}-35.6 \mathrm{~kg} / \mathrm{m}^{2}$

Oedema -no
CNS-conscious /well oriented

CVS- S1 S2 clear 
Effective Management of Pcos (Polycystic Ovarian Syndrome) through Ayurvedic Panchakarma Therapy Virechan : A Case Study

RS- clear AEBE P/A-soft non tender

Stool-NAD

Following treatment was given -

Virechan

. Virechan therapy was administered in the following manner-

\section{Poorvakarma for Virechan}

Deepan,Pachan-Is the first poorvakarma which is performed with the objective to get rid of the ama \& dhatvagnivardhan. (for the improvement in digestive fire)-With chitrakadi vatii 2 tab Two times in a day after meal \& hingwashtak churna 4 gm B.D. Before meal,Gandharvaharitaki churna $10 \mathrm{gm}$ with warm water at night for four days.

Snehapaan (Internal oliation) -, first dayTest dose (30ml) of phalaghruta was introduced. gradually the dose of Ghruta was increased i.e. $60 \mathrm{ml} ., 90 \mathrm{ml}$. \& then $120 \mathrm{~m}$.l.in this manner internal oliation was done till samyak snenahlakshan arises. i.e.Vataanuloman \&Agnideepti It was observed that after completion of internal oliation symptom of Burning sensation was cured \& Appetite was improved.

Rest -Three day rest include -Bahya Snehan and Swedan- After the appearance of samyaksnehan symptoms patients was advised to take rest for 3 day. Sarvang snehan with til tail\& Sarvang swedan through NadiSwedan with Dashmool Bharad was done on the rest day. It causes mrudutva and vilayana(liquefication) of accumulated doshas; increase the local blood supply and liquefies the mucous; makes the drug absorption faster due to vasodilatation of blood vessels.

- On the fourth day Virechan withTrivruttaleha 50 g.m. \& ErandSneha 40 m.l.was given .pt was observed for the samyak lakshanas.

- Samsarjan Kram for 7 days.

After Sansarjana karma blood investigations were done.

The severity of symptoms $\downarrow \downarrow$

Following test were done after one month

\begin{tabular}{|l|l|l|}
\hline PARAMETERS & $\begin{array}{l}\text { BEFORE TREATMENT } \\
\text { D0 }\end{array}$ & $\begin{array}{l}\text { AFTER VIRECHANA } \\
\text { D30 }\end{array}$ \\
\hline $1 . \quad$ Weight & $80 \mathrm{~kg}$ & $74 \mathrm{~kg}$ \\
\hline $2 . \quad$ BMI(Body Mass Index) & $35.6 \mathrm{~kg} / \mathrm{m}^{2}$ & $32.9 \mathrm{~kg} / \mathrm{m}^{2}$ \\
\hline $3 . \quad$ Lipid Profile & & \\
\hline S.Cholesterol & $310 \mathrm{mg} / \mathrm{dl}$ & $201 \mathrm{mg} / \mathrm{dl}$ \\
\hline S.Triglyceride & $274 \mathrm{mg} / \mathrm{dl}$ & $160 \mathrm{mg} / \mathrm{dl}$ \\
\hline HDL & $57 \mathrm{mg} / \mathrm{dl}$ & $52 \mathrm{mg} / \mathrm{dl}$ \\
\hline LDL & $298 \mathrm{mg} / \mathrm{dl}$ & $107.6 \mathrm{mg} / \mathrm{dl}$ \\
\hline VLDL & $54 \%$ & $41.4 \%$ \\
\hline $4 . \quad$ L.H. & 6.31 & 4.22 \\
\hline $5 . \quad$ F.S.H. & $2.08 \mathrm{miu} / \mathrm{ml}$ & $4.020 \mathrm{miu} / \mathrm{ml}$ \\
\hline
\end{tabular}

\section{DISCUSSION}

As there is no direct reference of PCOS in our classics, depending upon the symptoms it can be correlated to Arthavakshaya as delayed menstruation is one of the main symptoms observed. The symptoms of PCOS can also be compared to Bahudoshavastha. Shown In Arthavakshaya Sanshodhana and Agnivardhaka Chikitsa was advised by Acharya Sushruta. In Bahudoshavastha also Sanshodhana is the main line of treatment thus Virechana is planned. It is Kapha Vata Pradhana condition associated with Agnimandavastha. Virechana is bio cleansing in nature. It removes the metabolic waste, accumulated toxins and vitiated Dosha from the body. It also helps in regularising the disturbed hormonal levels in the body. Virechana also works on liver metabolism thus correcting the disturbed lipid levels. Sanshodhana works on correcting the internal pathology. After Shodhana 
the changes in the USG, as reduction in the ovarian volume and decrease in number of non-dominant follicles are positive changes. This shows that there is correction at hormonal level after Shodhana.

\section{RESULT}

Respond to the treatment was recorded and therapeutic effects were evaluated by symptomatic relief of the patient It was observed that the patient's clinical symptoms were reduced gradually after the treatment period.

\section{CONCLuSion}

PCOS is a endocrinological metabolic disorder, resulting due to faulty lifestyle and stress. It can be compared to Arthavakshaya.Sanshodhana can be better line of management for PCOS, as it works on correcting the underlying root cause and treat the disease. after detoxification of the body patient has to be advised to follow healthy life style.

It is concluded that this treatment regimen completely relieves the symptoms in PCOS.Sanshodhan can be done in treating patients who are suffering from $P C O S$, to reduce both signs \& symptoms successfully \& with greater effectiveness.

\section{REFERENCES}

[1] API Textbook of medicine seventh edition-2003, Editor Siddharth N.Shah, chapter XIX -Rheumatology pg no. 1157

[2] Kaviraj Atrideo Gupta -A.Hr. Chapter 22/13, Fourteenth edition -2003Editor -Vd.Yadunandan upadhyay Publisher-Chaukhambha Sanskrit Sansthan -Page no-423

[3] Bramhanand Tripathi-Charak Samhita-Chikitsasthan Chapter 29/88, Publisher - Chaukhambha Surbharati Prakashan Page no.998

[4] Bramhanand Tripathi-Charak Samhita-Chikitsasthan Chapter 29/23, Publisher - Chaukhambha Surbharati PrakasPage no. 987

[5] Bramhanand Tripathi -Charak Samhita-Chikitsasthan Chapter 29/121 Publisher - Chaukhambha Surbharati PrakasPage no.1002

Citation: RITU WADHWA (2020). Effective Management of Pcos (Polycystic Ovarian Syndrome) through Ayurvedic Panchakarma Therapy Virechan : A Case Study. International Journal of Medicinal Plants and Natural Products (IJMPNP), 6(1), pp.1-4. http://dx.doi.org/10.20431/2454-7999.0601001

Copyright: (0) 2020 Authors, this is an open-access article distributed under the terms of the Creative Commons Attribution License, which permits unrestricted use, distribution, and reproduction in any medium, provided the original author and source are credited. 